\title{
Maritime English - What Does It Communicate?
}

\author{
Adelija Čulić-Viskota, Sara Kalebota ${ }^{a}$
}

Maritime English is said to be a product of life on the ocean itself. It may be considered as the cradle of what is nowadays known as a type of ESP for the purposes of maritime communications. This paper presents an account of the rise of Maritime English as a type of ESP. It deals with the characteristics of ESP and how well Maritime English fits into the frame. Furthermore, the reciprocating influences of General English and Maritime English are presented and examples of both are provided to illustrate the vivid interaction between the two. Finally, an attempt is made to view the future development of Maritime English as based on the present-day conditions and future requirements.

\section{KEY WORDS:}

$\sim$ Maritime English

$\sim$ ESP

$\sim$ Maritime history

Faculty of Maritime Studies in Split, Zrinsko-Frankopanska 38, 21000 Split, Croatia, e-mail: adelija@pfst.hr

a. Primary school Petar Berislavić, Obala bana Berislavića 16, Trogir, Croatia e-mail: sakalebo@hotmail.com

\section{INTRODUCTION}

It is definitely not by accident that English has assumed the responsibility for maritime communications, not only business but also communication among multinational, multicultural and multilingual crew members on board vessels worldwide. The communicative role of Maritime English is deeply rooted in centuries-long British seafaring tradition but it has grown eventually to become a proper jargon related to a branch of human activity. It simultaneously extends its influence to the General English while making specific use of it, and to other ESP varieties that it comes across. Crewmembers on board make varied use of it according to their specific needs, but what is common to all of them is appropriate communication, both spoken and written, that contributes to the safety of navigation.

\section{THE RELATEDNESS OF THE ENGLISH MARITIME HISTORY TO LANGUAGE}

What is today known as the territory of Great Britain was connected to the European continent long before the human period began, that according to the findings of the Ancient Human Occupation of Britain project (AHOB) ${ }^{1}$ was about 500,000 years ago. The land link to the continent later widened, and climate changes forced pre-historic population out of and again

1. The Ancient Human Occupation of Britain project whose third phase is currently under way has been funded by the Leverhulme Trust. The results have been made available through publications, conferences, databases, a television series and a website: see www.nhm.ac.uk/hosted_sites/ahob/ 
into what is now Britain. Thus, the inhabitants were forced to get first into contact with the sea if they wanted to make any contacts with the neighbouring areas and their inhabitants. First, they had to cross the ocean to inhabit the Islands and later they had to cross it back for various purposes.

The beginning of the maritime history of England is believed to date back to the Iron Age Phoenician traders describing the trade routes to England around 600 BC. They were succeeded by the Ancient Greeks who provided a detailed description of their sea voyages from Massilia, present-day Marseilles, along the western Mediterranean to Britain some three centuries later. ${ }^{2}$ These were in fact the ancient pilot books called peripli from Latin singular periplus originating from Greek пврілт入ои meaning sailing around or circumnavigation. Eventually, the meaning broadened to include "a manuscript document that listed, in order, the ports and coastal landmarks, with approximate intervening distances, that the captain of a vessel could expect to find along a shore. ... the Greek navigators added various notes, which if they were professional geographers (as many were) became part of their own additions to Greek geography. In that sense the periplus was a type of log."

The Britons inhabiting the area of the Island to the south of the Firth of Forth ${ }^{3}$ already before the Roman Iron $\mathrm{Age}^{4}$ are of unknown origin. They are supposed to have reached the Island from Armenia, which is thought to be a mistaken transcription of Armorica, an area in North-Western Gaul ${ }^{5}$. They are also known for periodically moving to continental Europe, where they founded the settlements of Brittany in France and the littleknown Britonia is what is now Galicia in north-west Spain.

The first boats used by the Britons are believed to have been rafts, canoes dug out from tree trunks and coracles. They are supposed to have mainly been used for fishing and transport on rivers. According to the archaeological findings, the oldest known ocean-going boat related to the British Isles dates back

2. "The Massaliote Periplus or Massaliot Periplus is a now-lost merchants' handbook possibly dating to as early as the 6 th century $B C$ describing the sea routes used by traders from Phoenicia and Tartessus in their journeys around Iron Age Europe. Massalia, however, was a Greek colony.It was preserved by the Roman poet Avienus in his work Ora Maritima (The Maritime Shores) who wrote down parts of it much later, during the 4th century AD.It contained an account of a sea voyage from Massilia (Marseilles) along the western Mediterranean.

It describes seaways running northwards from Cadiz in Spain along the coast of Atlantic Europe to Brittany, Ireland and Britain. The Periplus is the earliest work to describe the trade links between northern and southern Europe. That such a manual existed indicates the importance of these trade links. The trade in tin and other raw materials from the British Isles southwards is attested by archaeological evidence from this period and earlier and the riches to be won probably attracted numerous adventurers to explore and exploit the Atlantic coasts. Pytheas of Massilia described a similar expedition in more detail a few centuries later, around 325 BC." (retrieved from: http://en.wikipedia.org/wiki/Massaliote_Periplus)

3. Firth of Forth is the estuary or firth of the river Forth in the southern part of Scotland

4. Koch, pages 291-292 (Koch, 2006)

5. The Anglo-Saxon Chronicle to the Bronze Age, approximately 1600 BC. It was named the Dover Bronze Age Boat after the area in which it was excavated in 1992. Its length is $9.5 \mathrm{~m}$, beam $2.3 \mathrm{~m}$, it is thought to have been propelled by a crew of between 4 and 16 paddlers and to have reached speed up to 5 knots. It could also carry some cargo.

During the Roman period maritime expeditions to the Island were frequent, as well as invasions and trade contacts with Britain and later from there to Europe.

In the second half of the $3^{\text {rd }} \mathrm{ct}$. the shores of Britain were under frequent attacks by the Picts and Scots as well as the Germanic tribes of Angles, Saxons and Jutes. The latter were even recruited as mercenaries to assist the British kings. They eventually established control over the south-eastern areas of England. From the east coast of Britain many trade lines went across the North Sea while the west coast continued trade with the Mediterranean. So, the sea-borne trade stimulated migrations from southern England to Brittany and northern Spain.

As early as in 730s ships that used the port of London for trading had to pay a toll ${ }^{6}$ that would later become what is known as harbour dues.

From the $9^{\text {th }} \mathrm{ct}$. the Vikings frequently attacked Britain and simultaneously traded with the help of their longships propelled by both oars and sails. A significant feature of their vessels was a steering oar (or board) at the back on the right-hand side that will later result in the term starboard designating the right-hand side in Maritime English and the term port ${ }^{7}$ left-hand side. Later, in 1066 the Normans conquered Britain after a sea-borne attack followed by a lot of trade across the English Channel. The British also fought against the French, Portuguese and Irish; therefore, they required naval transport for the army and its support. Another later ship design, the cog, is believed to have been influenced by the longship. The rudder was now fixed to the stern post, thus facilitating the steering. There were also more masts and a more abundant sail wardrobe to increase the ship's speed.

6. Toll = a charge, fee or tax for the privilege of using a structure, in this case the port

7. The explanation found at the British National Maritime Museum web page: http://www.rmg.co.uk/explore/sea-and-ships/facts/faqs/customs-andorigins/port-and-starboard

"If starboard is the right-hand side of the vessel, looking forward from aft, the left-hand side is port - at least, it is now! In Old English, the term was bæcbord (in modern German Backbord and French bâbord), perhaps because the helmsman at the steorbord had his back to the ship's left-hand side. This did not survive into Medieval and later English, when larboard was used. Possibly this term is derived from laddebord, meaning 'loading side'; the side rudder (steorbord) would be vulnerable to damage if it went alongside a quay, so early ships would have been loaded ('laded') with the side against the quay. In time laddebord became larboard as steorbord became starboard. Even so, from an early date port was sometimes used as the opposite for starboard when giving steering orders, perhaps deriving from the loading port which was in the larboard side. However, it was only from the mid-19th century that, according to Admiral Smyth's The Sailor's Word Book, published in 1867, 'the left side of the ship is called port, by Admiralty Order, in preference to larboard, as less mistakable in sound for starboard". 
During the rise of the Hanseatic league the trading guilds extended their commerce over the Baltic and part of the North Sea in the Late Middle Ages when warehouses were established for the League in English and Scottish ports. At nearly the same time seamen's guilds, the predecessors of modern seamen's clubs were established all over Britain. Thus, the English merchant fleet started developing after the League collapsed.

From the $15^{\text {th }}$ to the $17^{\text {th }} \mathrm{ct}$. the British travelled all around the world in search of new markets and trading relations, established new trading routes contributing at the same time to the exploration of unknown lands and peoples. Once the British established their colonies worldwide, they set up trading relations supported by their emerging merchant fleet. The English ships were seaworthy, but required a lot of crew. Thus, they could not be competitive in the newly rising maritime shipping market. When they captured several Dutch merchant ships in the wars they fought, they first made them part of their own merchant fleet and subsequently applied newly-acquired techniques to building their own new ships. The results were ships with a larger stowage area due to a longer keel, but with a reduced number of crewmembers. Thus, the first part of the $17^{\text {th }} \mathrm{ct}$. was a period in which the English maritime shipping flourished due to trading relations with the Mediterranean, East Indies ${ }^{8}$ and North America.

The English naval fleet established by Alfred the Great declined after defeating the Vikings but it recovered in the $10^{\text {th }}$ ct. when the Norman invasion was threatening. The Normans conquered England nevertheless, as the English fleet was previously damaged in a storm and was not able to oppose the conquerors. After the Normans had become rulers of England, they established a naval fleet in the $12^{\text {th }}$ and $13^{\text {th }} \mathrm{ct}$. that made a total of some 500 ships, while in the following century the number increased to more than 700 . The $15^{\text {th }}$ and $16^{\text {th }} \mathrm{ct}$. saw the beginning of building specialised warships larger than merchant ships. Their number amounted to 40 by the 1550 s, and were characterized by gunports designed to carry heavy guns. For this purpose new shipyards had been founded. But the navy was not supported by appropriate funds which weakened the defence of the British coast. In the following centuries the English naval fleet was reformed and improved again, and the institution of the Admiralty was founded in 1545 as the fleet had already for two centuries been commanded by admirals. This led to establishing the post of Lord Admiral of England in 1408. The important difference lay in the fact that now the Admiralty had control of naval operations and ships' officers and that the First Lord of the Admiralty was a civilian and a member of the Government. In the $17^{\text {th }} \mathrm{ct}$. the first Fighting Instructions were issued, and in 1673 the first Sailing Instructions appeared.

8. East Indies is a term used by Europeans from the 16th century onwards to identify what is now known as the Indian subcontinent, Southeastern Asia, and the islands of Oceania and Maritime Southeast Asia.

(retrieved from: http://en.wikipedia.org/wiki/East_Indies, May 6, 2013)
The oldest traces of shipbuilding in England date back to the $9^{\text {th }}$ into $10^{\text {th }}$ ct., i.e. to the cargo boat found in Graveney, Kent. According to Fenwick and Morley (Fenwick and Morley, 1978) the boat measuring roughly 14 per 4 metres was used for carrying the cargo of quernstones from the Middle Rhine to the Thames. Another $13^{\text {th }} \mathrm{ct}$. boat was found on the river Severn which proves that the early British boatbuilding existed in rivers and streams close to the coast.

Ship design developed over time: ships were increasingly fitted, first with decks to obtain closed space around the $12^{\text {th }} \mathrm{ct}$. and by the beginning of the $13^{\text {th }}$ century with stern-mounted rudders. The number of masts also increased in the following centuries as well as the number and area of the sails. By the $16^{\text {th }}$ ct. there were about 60 types of vessel among which the most famous was the cog and carvel developed under the Portuguese influence. They were accompanied by the English galleon featuring gunports from the mid- $16^{\text {th }} \mathrm{ct}$. This was the period in which the region of the river Thames became the leading shipbuilding area.

\subsection{Privateering and piracy: robbery at sea}

Along with the rise of maritime affairs in what is now Britain there appeared some other less plausible activities such as privateering and piracy. The difference between the two was in the aspect, i.e. privateers were authorized to capture enemy ships, while pirates were not. In the early $16^{\text {th }} \mathrm{ct}$. pirates were considered as offenders of the civil law, and there are records of persons convicted and hanged for piracy.

Nevertheless, the British rulers allowed and commissioned attacks they considered favourable for their country in the current circumstances. Thus, ship captains were joined by merchants and gentlemen to fit out ships that were expected to defeat foreign fleets and take over their treasure as well as explore and plot new merchant paths. So, in this period valuable charts of the East were produced.

In the $17^{\text {th }} \mathrm{ct}$. the pirates from North Africa used to attack British ships so that by the mid- $17^{\text {th }} \mathrm{ct}$. an expedition against them started in the Caribbean. Thus, the English now had their own pirate leaders operating in the Atlantic and Caribbean. To make this activity cease, in 1700 an Act of Parliament was passed by which pirates had to be brought before Vice Admiral's Court.

All sea-related affairs obviously required a specific jargon serving the life and activities on board as well as in the occasions of discussing them either among the educated persons (e.g. the legal aspect of a maritime venture) or laymen (e.g. describing it among the villagers). This fact definitely gave rise to a special domain of English in which general and specific meet in a friendly manner both prospering from each other's company but at the same time remaining distinct entities. 


\section{THE RISE OF MARITIME ENGLISH AS A TYPE OF ESP: ITS NARROWER AND BROADER SENSE}

\subsection{The growth of ESP}

The origins of ESP are a widely discussed topic. The most plausible reasons for its appearance seem to be those noted by Hutchinson and Waters (Hutschinson and Waters, 1987): 1. the demands of a Brave New World arising with the growth of economic power of the USA in the period following World War $\mathrm{II}$, as well as the prosperity of oil-rich countries during the oil crisis in the early 1970s; 2 . a revolution in linguistics brought about by a change of the object of investigation that ceased to be the language itself and turned to its communicative aspect; 3 . focus on the learner with specific requirements that had to be met by investigating specific contexts and designing appropriate courses. The authors provide a guideline in the title itself, i.e. "a learning-centred approach". This means firstly, that the researchers' interest is focused on the process of language acquisition including the learner, and secondly, that ESP should not be considered as the product but as a possible approach to meeting the requirements of the user (Hutchinson and Waters (Hutschinson and Waters, 1987). Some ten years later DudleyEvans \& St. John (Dudley-Evans and St. John, 1998) proposed some absolute and variable characteristics to better delineate the definition of ESP. The absolute characteristics are:

1) Designed to meet specific needs of the learners;

2) Makes use of the underlying methodology and activities of the disciplines it serves;

3) Centred on the language (grammar, lexis, register), skills, discourse and genres appropriate to these activities.

The variable characteristics are:

1) ESP may be related to or designed for specific disciplines;

2) ESP may use, in specific teaching situations, a different methodology from that of general English;

3) ESP is likely to be designed for adult learners, either at a tertiary level institution or in a professional work situation. It could, however, be used for learners at secondary school level;

4) ESP is generally designed for intermediate or advanced students. Most ESP courses assume basic knowledge of the language system, but it can be used with beginners.

\subsection{The distinction of Maritime English as a specific jargon}

According to the above mentioned characteristics Maritime English constitutes an ESP course as all of the seven features apply to it. Still, any attempt at a further delineation of Maritime English as taught at the Faculty of Maritime Studies presents new problems. It cannot be restricted to English for
Vocational Purposes (EVP) as this is only a part of its scope. In the Bachelor curriculum vocational purposes meet professional (EPP) thus fitting into both branches of English for Occupational Purposes (EOP). Furthermore, in the Master curriculum English for Academic Purposes in Science and Technology (EST) as well as Business English (BE) also have to be included. Therefore, Maritime English may be perceived as a direct proportion of the number of traits involved and the level of study. This is all due to maritime profession having become interdisciplinary up to the point of involving business, medicine, technology and science as well as their specific Englishes.

From the linguistic point of view Maritime English is a specific jargon. But, it also implies a specific style embodied in specific grammatical forms, or as in (Miller, 1981) states about his work on the jargons: "... I started to see things differently. I found that each variation on the language, much as it might be abused, contained something fascinating that I had not expected: it revealed the basic mind-set, the underlying style of thinking and perceiving of each singular discipline and the people who inhabit it." This is how Maritime English may be perceived in its broader sense.

It was the Resolution $\mathrm{A} .380(\mathrm{X})$ adopted by IMO General Assembly in 1977 in virtue of which English was recognized as "a common language for international communications between ships and between ships and shore services." (Bocanegra Valle, 2013) It was the official recognition of Maritime English as the workhorse in the maritime profession. It first meant a specific vocabulary (Maritime English in the narrower sense of the term), but as time went by, it began to take shape of a more complex communicative tool. Consequently, its teaching aspect has been elaborated on and its curricula standardized in the IMO Model Course 3.17 designed to meet the requirements of STCW.

\section{COMPARISONS AND CONTRASTS BETWEEN GENERAL ENGLISH AND ESP}

Let us first introduce different terms and acronyms related to the topic. ESP itself may either stand for English for Specific Purposes or English for Special Purposes, the latter being felt as an outdated term although it can still be found as representing a superordinate term to English for Specific Purposes in that special purposes include different specific purposes.

ESP is usually opposed to EGP standing for English for General Purposes, or as it appears in TENOR, an acronym meaning Teaching English for No Obvious Reason (Lowe, 2009). Maritime English is definitely taught for a very specific purpose. Still, this does not mean that it is a self-sustaining separate entity. It certainly makes abundant use of the general language ascribing to its lexical units new meanings, thus enriching its lexical aspect. Furthermore, ESP can often present quite unexpected uses of standard grammar in order to convey specific meanings. 


\subsection{Maritime English and General English on Reciprocating Courses}

General English may be perceived as the starting point for different specific jargons as all of them arise on the basis of the General incorporating its lexical units and basic grammar. Here starts the process of diversification which implies a detachment from the General, but also its enrichment with new meanings ascribed to the existing body. Sometimes these diversifications become highly specific and elaborate to the point of becoming hardly understandable to the speakers of General English. Thus, Miller (Miller, 1981) observes: "Often within a single family, between brothers and sisters, or between lovers or old friends there exists a special, secret language, unknown to the rest of the world, which carries an intimate set of meanings and associations. In my own experience I have found these to be among the most beautiful forms in which language can be used."

\subsection{General English lexical units resulting into Maritime English terms}

For specific purposes Maritime English has preferences for certain lexical items rather than others with synonymous meaning so as to ensure the highest intelligibility and least possibility of misunderstanding. Thus, it prefers to alter course instead of changing it (although in the General both are acceptable) as the more out-of-the-way lexical item is certainly harder to misunderstand, especially in the shipping environment that has for some time now been made increasingly hectic and communication has turned into a babel due to a large number of world Englishes used by again increasingly multinational crews. Furthermore, there are lexical units whose basic meaning takes on jargon-specific features. Thus, e.g. the sailing manoeuvre known as tacking derives from the General English verb to tack dating back to the $14^{\text {th }}$ century Middle English takken related to tak meaning something that fastens one thing to another and probably related to Old French tache for a clasp, large nail ${ }^{9}$. The noun comes in its first meaning a small, sharp broad-headed nail, followed by a North American meaning of a drawing pin, next by the meaning of a long stitch used to fasten fabrics together temporarily, prior to permanent sewing. After that comes the meaning which is more abstract: a method of dealing with a situation or problem; a course of action or policy. Finally, there comes the meaning characteristic of sailing: to make a series of changes of course while sailing; to alter course by turning a boat's head into and through the wind, which of course denotes the steps taken to perform the alteration of course during sailing, but it nevertheless implies the above mentioned

9. http://oxforddictionaries.com/definition/english/tack (April 12, 2013) change of tactic as proposed in the meaning to modify one's policy or attitude abruptly ${ }^{10}$. Likewise, the verb to gybe, alternatively spelt to jibe, deriving possibly from the late $17^{\text {th }}$ century obsolete Dutch verb gijben, present-day gijpen, is used with the General English meaning to make a sailing manoeuvre shifting a fore-andaft sail from one side of a vessel to the other while sailing before the wind so as to sail on the opposite tack or from the Middle French giber, meaning to shake or handle with force ${ }^{11}$. Jibe, as a noun, is a versatile word with several meanings, including to be in harmony or in agreement (e.g. let's see if our calculations jibe) ${ }^{12}$. There is of course a rich array of terms arisen from the General language which have gone through different processes of specification of meaning to become proper Maritime English terms.

\subsection{Influences of Maritime English on General English}

As seafarers and sailing enthusiasts take their experiences along even after disembarking and their activities while on board have significant effect on the formation of their worldview, the influences of Maritime English on General English are numerous. To illustrate this there are examples such as:

all at sea (Br.E.) / at sea (Am.E.) meaning completely confused, lost and bewildered ${ }^{13}$ as in:

It was his first day at the University, so he felt all at sea / completely at sea.

Sea legs meaning first the ability to keep one's balance when walking on a moving ship and not feel ill as in:

It took me a while to get my sea legs, but I feel fine now. (ibid.)

A second meaning can be to get used to a new situation as in:

After graduating from college he went to Chicago to get his sea legs by working in radio.

To batten down the hatches deriving from a nautical expression meaning to seal the hatches against the arrival of a storm (ibid.) but having also a figurative meaning to prepare for difficult times as in:

When you're coming down with a cold, all you can do is batten down the hatches and wait for the body to fight it off.

Feeling blue or feeling sad also derives from the age of deepwater sailing ships, which on e.g. losing their Captains or Officers during a voyage would fly a blue flag and have a blue

10. http://www.merriam-webster.com/dictionary/tack (April 12, 2013)

11. http://owad.de/check.php4? wordid=1630\&choice $=3 \&$ PHPSESSID $=710 \mathrm{dd} 862$ e74e02dec17e6476cb68780b (April 12, 2013)

12. Ibid.

13. Sources: http://www.englishclub.com/ref/esl//dioms/A/at_sea_all_at_ sea_140.htm (April 19, 2013); http://idioms.thefreedictionary.com/sea (April 19, 2013); Cambridge Idioms Dictionary, $2^{\text {nd }}$ edition, CUP 2006; McGraw-Hill Dictionary of American Idioms and Phrasal Verbs. @ 2002 by The McGraw-Hill Companies, Inc. 
band painted along the entire hull when returning to home port. (ibid.)

To know/learn/show/teach the ropes deriving from the early days of sailing when the phrase He knows the ropes. written on seafarer's discharge meant that he was still a novice and all he knew about the job was theory, or the names and uses of the principal ropes or lines. But the phrase has changed meaning and at present it means that the person fully knows and understands the operation, as in:

It'll take some time for the new receptionist to learn the ropes.

or in:

The new secretary started today so I spent most of the morning showing her the ropes.

The above mentioned idioms and phrases are just the tip of the iceberg. Fortunately, further discussion of the kind could only be enlightening.

\section{CONCLUSION}

With its centuries-long maritime history the English language has become the language of the seven seas. Influences of General English and Maritime English can be perceived as mutual or reciprocal. General English definitely represents the basis from which a rich array of the jargons actually in use have stemmed. On the other hand, the vividness of jargon stylistic means fostered by its deep rootedness in specific situations contributes significantly to the semantic abundance and versatility of General English. Regarding the status of Maritime English it can rightfully be emphasized that due to its standardization referring to the existing and new areas of interest in shipping, and increasing efforts at teaching Maritime English at maritime colleges and universities worldwide, it has contributed to preventing maritime accidents. A possible future development might also include ship's rating ranks as it would definitely ease both their lateral/horizontal and hierarchical/top-down, bottomup communication.

\section{REFERENCES}

Anglo-Saxon Chronicle, available at: http://avalon.law.yale.edu/medieval/ang01. asp, [accessed 9 December 2012.]

Bocanegra Valle, A., (2013), Maritime English. In Chapelle, C. A. (ed.), The Encyclopedia of Applied Linguistics, West Sussex: Wiley-Blackwell.

Born, J., (2012), The Norseman. CreateSpace Independent Publishing Platform.

Britannia History, available at: http://www.britannia.com/history/docs, [accessed 17 January 2013.].

Britannia History, available at: http://www.britannia.com/history/docs, [accessed 17 January 2013.]

Chartrand R., Durham, K., Harrison, M. and Heath I., (2006), The Vikings, Voyagers of Discovery and Plunder. Oxford: Osprey Publishing Ltd.

Cunliffe, B.,(2001), Facing the Ocean. The Atlantic and its peoples, Oxford: OUP.

Cunliffe, B., (2001), The extraordinary voyage of Pytheas the Greek, Harmondsworth: Penguin.

Davis, R., (1962)., The Rise of the English Shipping Industry in the 17th and 18th Centuries. Newton Abbot: David \& Charles.

Dudley-Evans, T., \& St. John, M. J., (1998), Developments in English for specific purposes: A multi-disciplinary approach. Cambridge: Cambridge University Press.

Enhanced Language Training Initiative: Formative Evaluation, http://www.cic.gc.ca/ english/department/partner/elt-spo.asp, [accessed 17 January 2013.].

Fenwick,V. \& A. Morley, (1978), The Graveney boat: a tenth century find: excavation and recording; interpretation of the boat remains and the environment; reconstruction and other research conservation and display. Oxford: British Archeological Reports.

Harrison, M., (2006), The Vikings: Voyagers of Discovery and Plunder. New York: Osprey Publishing.

Hutchinson, T. \& Waters, A., (1987), English for Specific Purposes: A learning-centred approach. Cambridge: CUP.

Koch, John T., (2006), Celtic Culture: A Historical Encyclopaedia. Santa Barbara: ABCCLIO.

Lowe, I., (2009), Principles of ESP course design, available at: http://www. scientificlanguage.com/swp/coursedesign.pdf, [accessed 11 March 2013.].

Miller, D.E., (1981), The Book of Jargon. New York: McMillan Publishing Co.

Port-and-starboard, available at: http://www.rmg.co.uk/explore/sea-and-ships/ facts/faqs/customs-and-origins/port-and-starboard, [accessed March 20, 2013.]

Snyder, C. A., (2003), The Britons. Padstow: Blackwell Publishing. 